\title{
In vitro cytotoxicity of biosynthesized titanium dioxide nanoparticles in human prostate cancer cell lines
}

\author{
Feiping He ${ }^{1,2}$, Weixing $\mathrm{Yu}^{2}$, Xiaosong Fan ${ }^{2}$, Baiye $\mathrm{Jin}^{1 *}$ \\ ${ }^{1}$ Department of Urology, The First Affiliated Hospital, Zhejiang University, Hangzhou 310003, Zhejiang, ${ }^{2}$ Department of Urology, \\ Shaoxing Shangyu People's Hospital, Shaoxing 312300, Zhejiang, China
}

*For correspondence: Email: baiyejin@hotmail.com; Tel/Fax: 0086-571-87236666

\begin{abstract}
Purpose: To establish a green method for production of titanium dioxide $\left(\mathrm{TiO}_{2}\right)$ nanoparticles (NPs) using Cinnamomum tamala (C. tamala) leaf extract, and examine the in vitro cytotoxicity of the product in a human prostate cancer (D145) cell line.

Methods: $\mathrm{TiO}_{2}$ NPs were synthesized by mixing $20 \mathrm{~mL}$ of $\mathrm{C}$. tamala leaf extract with $0.1 \mathrm{M}$ titanium dioxide $\left(\mathrm{Ti}(\mathrm{OH})_{2}\right)(80 \mathrm{~mL})$ in aqueous solution with stirring for $2 \mathrm{~h}$ at room temperature. The $\mathrm{TiO}_{2} \mathrm{NPs}$ were characterized using $x$-ray diffraction (XRD), Fourier transform infrared spectroscopy (FT-IR), $x$-ray photoelectron spectroscopy, dynamic light scattering (DLS), transmission electron microscopy (TEM), selected-area electron diffraction, and energy dispersive $x$-ray spectroscopy. The in vitro cytotoxicity against D145 cells was determined using a 3-(4, 5-dimethylthiazol-2-yl)-2, 5-diphenyltetrazolium bromide assay.

Results: TEM and DLS analyses showed that the NPS were irregularly shaped, with an average particle size of $23 \mathrm{~nm}$. The FT-IR spectrum of C. tamala leaf extract showed that the biomolecules were potentially involved in reduction processes. The negative zeta potential of -14 mV indicated that the NPs were stable and discrete while their crystalline nature was confirmed by XRD. Cytotoxicity analysis showed that the $\mathrm{TiO}_{2} \mathrm{NPs}$ exhibit a dose-dependent toxic effect on D145 cells.

Conclusion: A facile and less expensive approach for the production of $\mathrm{TiO}_{2} \mathrm{NPs}$ using C. tamala leaf extract has been developed. The $\mathrm{TiO}_{2} \mathrm{NPs}$ showed dose-dependent cytotoxicity towards D145 cells.
\end{abstract}

Keywords: Anticancer activity, Cinnamomum tamala, Green synthesis, Prostate cancer, $\mathrm{TiO}_{2}$ nanoparticles

\begin{abstract}
This is an Open Access article that uses a funding model which does not charge readers or their institutions for access and distributed under the terms of the Creative Commons Attribution License (http://creativecommons.org/licenses/by/4.0) and the Budapest Open Access Initiative (http://www.budapestopenaccessinitiative.org/read), which permit unrestricted use, distribution, and reproduction in any medium, provided the original work is properly credited.
\end{abstract}

Tropical Journal of Pharmaceutical Research is indexed by Science Citation Index (SciSearch), Scopus, International Pharmaceutical Abstract, Chemical Abstracts, Embase, Index Copernicus, EBSCO, African Index Medicus, JournalSeek, Journal Citation Reports/Science Edition, Directory of Open Access Journals (DOAJ), African Journal Online, Bioline International, Open-J-Gate and Pharmacy Abstracts

\section{INTRODUCTION}

Cancer is one of the leading causes of death worldwide, and is characterized by the proliferation of abnormal cells. There are a range of methods used to treat cancer, including surgery, chemotherapy, and radiotherapy.
However, the use of these standard methods is limited because they are expensive and have many side effects. Hence, effective, low-cost nontoxic treatments with fewer side effects are required. Nanomaterials with small diameters (1$100 \mathrm{~nm}$ ) exhibit unique physicochemical characteristics, including high surface area, 
enhanced reactivity, the ability to enter cells easily, and the ability to affect different biological systems. These unique interactions between nanoparticles (NPs) and biomolecules may have applications for cancer diagnosis and treatment [1-4]. Titanium oxide nanoparticles $\left(\mathrm{TiO}_{2} \mathrm{NPs}\right)$ have been used in a wide range of commercial applications, particularly in consumer products such as textiles, laundry additives, room sprays, water purifiers, and food storage containers [510].

$\mathrm{TiO}_{2}$ is a good photocatalyst, and is widely used in surface coatings as a self-cleaning and selfdisinfecting material. Moreover, it plays a key role in environmental purification due to its specific nontoxicity, photoaccelerated super hydrophobicity, and antifogging effects [11,12]. There are a range of advantages to using an inorganic nanomaterial such as $\mathrm{TiO}_{2}$ rather than an organic material in biomedical applications. These advantages include stability, easy of fabrication, less toxicity, heat-resistance, and sufficient durability in the absence of light exposure [13]. $\mathrm{TiO}_{2}$ NPs can be synthesized using a variety of methods such as hydrolysis, thermolysis, the sol/gel method [14], hydrothermal methods [15], and flame synthesis [16]. However, all of these methods require expensive and toxic chemicals. In this respect, green methods, which involve simple eco-friendly routes [17-19] for synthesizing nanomaterials have several advantages over chemical and physical methods.

In this study, we present an ecologically friendly method to synthesize $\mathrm{TiO}_{2}$ NPs from aqueous leaf extracts of Cinnamomum tamala (C. tamala). The prepared NPs were characterized using a range of techniques, and then investigated for anticancer activity in a human prostate carcinoma (D145) cell line.

\section{EXPERIMENTAL}

\section{Materials}

$\mathrm{Ti}(\mathrm{OH})_{2}$ powder was obtained from SigmaAldrich (St. Louis, MO, USA). The human prostate carcinoma (D145) cell line was obtained from the American Type Culture Collection (Manassas, VA, USA). Milli- $Q^{\circledR}$ water was used in all experiments.

\section{Preparation of plant extracts}

The leaves of the $C$. tamala plant were obtained from plants located nearby Zhejiang University in Hangzhou city in the month of June 2016, and later dried under sunlight and cross verified by
Xianchun Zhang, taxonomist at Chinese National Herbarium, Beijing, China. The voucher specimen for $C$. tamala leaves was kept for reference at the Chinese National Herbarium, Beijing, and the corresponding voucher number is 223. Fresh $C$. tamala leaves were thoroughly washed, initially with tap water, followed by Milli$\mathrm{Q}^{\circledR}$ water. The leaves $(20 \mathrm{~g})$ were boiled in 250 $\mathrm{mL}$ Milli- $\mathrm{Q}^{\circledR}$ water at $60^{\circ} \mathrm{C}$ for $15 \mathrm{~min}$. Unwanted solid particles were removed from the extract by filtering through Whatman No-1 filter paper (pore size: $11 \mu \mathrm{m})$.

\section{Green synthesis of nanoparticles}

To synthesize $\mathrm{TiO}_{2} \mathrm{NPs}$, approximately $80 \mathrm{~mL}$ of $0.1 \mathrm{M}$ titanium dioxide $\left(\mathrm{TiO}_{2}\right)$ aqueous solution was stirred for $2 \mathrm{~h}$ at room temperature. Then, 20 $\mathrm{mL}$ of leaf extract was added and the solution was stirred for an additional $24 \mathrm{~h}$. The particles were then repeatedly centrifuged and washed with ethanol and chloroform, and dried at room temperature for $24 \mathrm{~h}$.

\section{Characterization of nanoparticles}

Transmission electron microscopy (TEM) imaging, selected-area electron diffraction (SAED) patterning, and electron dispersive X-ray spectroscopy (EDS) analyses were carried out using a JEM 2100 high-resolution TEM system (JEOL, Tokyo, Japan) with an accelerating voltage of $200 \mathrm{kV}$. The X-ray diffraction (XRD) spectrum of the centrifuged and dried sample of $\mathrm{TiO}_{2}$ NPs was obtained using a Bruker D8 Advanced X-ray diffractometer with a copper potassium-alpha $(\mathrm{Cu}-\mathrm{K} \alpha)$ source $(\lambda=1.5406 \AA)$. The zeta potential of the synthesized NPs was measured using a Malvern Zetasizer Nano ZS90 counter (Malvern, UK) at $25{ }^{\circ} \mathrm{C}$. X-ray photoelectron spectroscopy (XPS) data were obtained using a Kratos Axis Ultra 165 spectrometer (Manchester, UK) with a monochromatic aluminum potassium-alpha (Al$\mathrm{K} \alpha)$ X-ray source $(h \alpha=1486.6 \mathrm{eV})$. The Fourier transform infrared (FT-IR) spectrum was recorded using a Shimadzu IRAffinity 1 spectrometer (Tokyo, Japan).

\section{In vitro cytotoxicity assessment}

An in vitro cytotoxicity assessment of the prepared $\mathrm{TiO}_{2} \mathrm{NPs}$ was conducted to investigate the viability and cellular fate of the D145 cells. The toxicity and cell viability of the D145 cells were investigated after exposing them to increasing concentrations of $\mathrm{TiO}_{2} \mathrm{NPs}(0.05,0.1$, and $0.5 \mu \mathrm{g} / \mathrm{mL}$ ). A cell counter was used to determine the percentage of viable cells after an incubation period of $48 \mathrm{~h}$. The control experiment 
was without $\mathrm{TiO}_{2} \mathrm{NPs}$. The cells remained $100 \%$ viable.

\section{Statistical analysis}

All of the cytotoxicity experiments were performed three times for each concentration. Absolute values of each experiment were converted into percentages. All data points corresponding to the concentration versus cytotoxicity plot are shown as the arithmetic mean percent inhibition compared to the control standard error. A one-way analysis of variance (ANOVA) was used to determine the statistically significant differences between the mean values. A value of $p<0.05$ was considered as significant.

\section{RESULTS}

\section{Characteristics of the $\mathrm{TiO}_{2}$ nanoparticles}

Figure 1 shows the XRD peaks of the $\mathrm{TiO}_{2} \mathrm{NPs}$ synthesized using the leaf extracts. The anatase phase was confirmed by the presence of $2 \theta$ values corresponding to $25.49^{\circ}, 37.82^{\circ}, 48.05^{\circ}$, $55.06^{\circ}$, and $62.60^{\circ}$. All of the observed peaks were in good agreement with the anatase phase (Joint Committee on Powder Diffraction Standards (JCPDS) CPDS no: 99-201-6205).

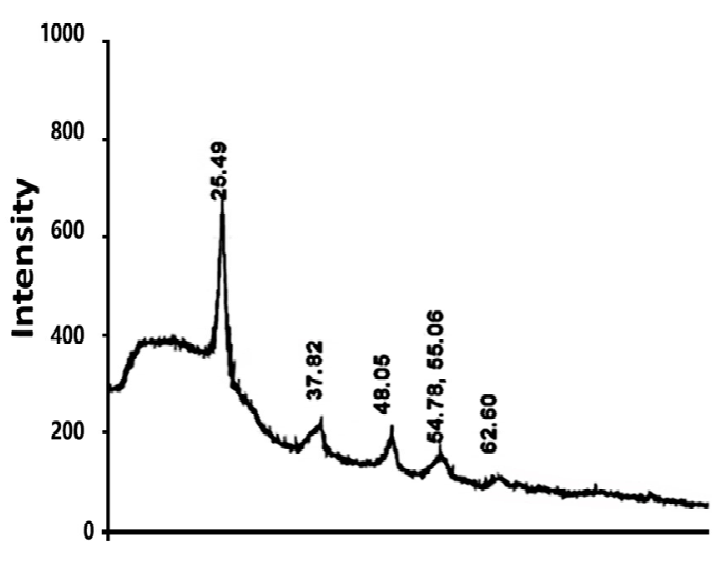

$2 \theta$

Figure 1: X-ray diffraction (XRD) peaks of greensynthesized titanium oxide nanoparticles

The synthesized NPs were $\sim 23 \mathrm{~nm}$ in size, as indicated by TEM images (Figures $2 \mathrm{a}, \mathrm{b}$ and Figure $3 \mathrm{~b}$ ). The stability of the NPs was determined based on their zeta potential value of $-14.0 \pm 0.52 \mathrm{mV}$ (Figure 3a). Thus, the $\mathrm{TiO}_{2} \mathrm{NPs}$ were stable and discrete in the aqueous medium used. No loss of stability was observed even after 6 months at room temperature. The NPs had an irregular morphology with little agglomeration.
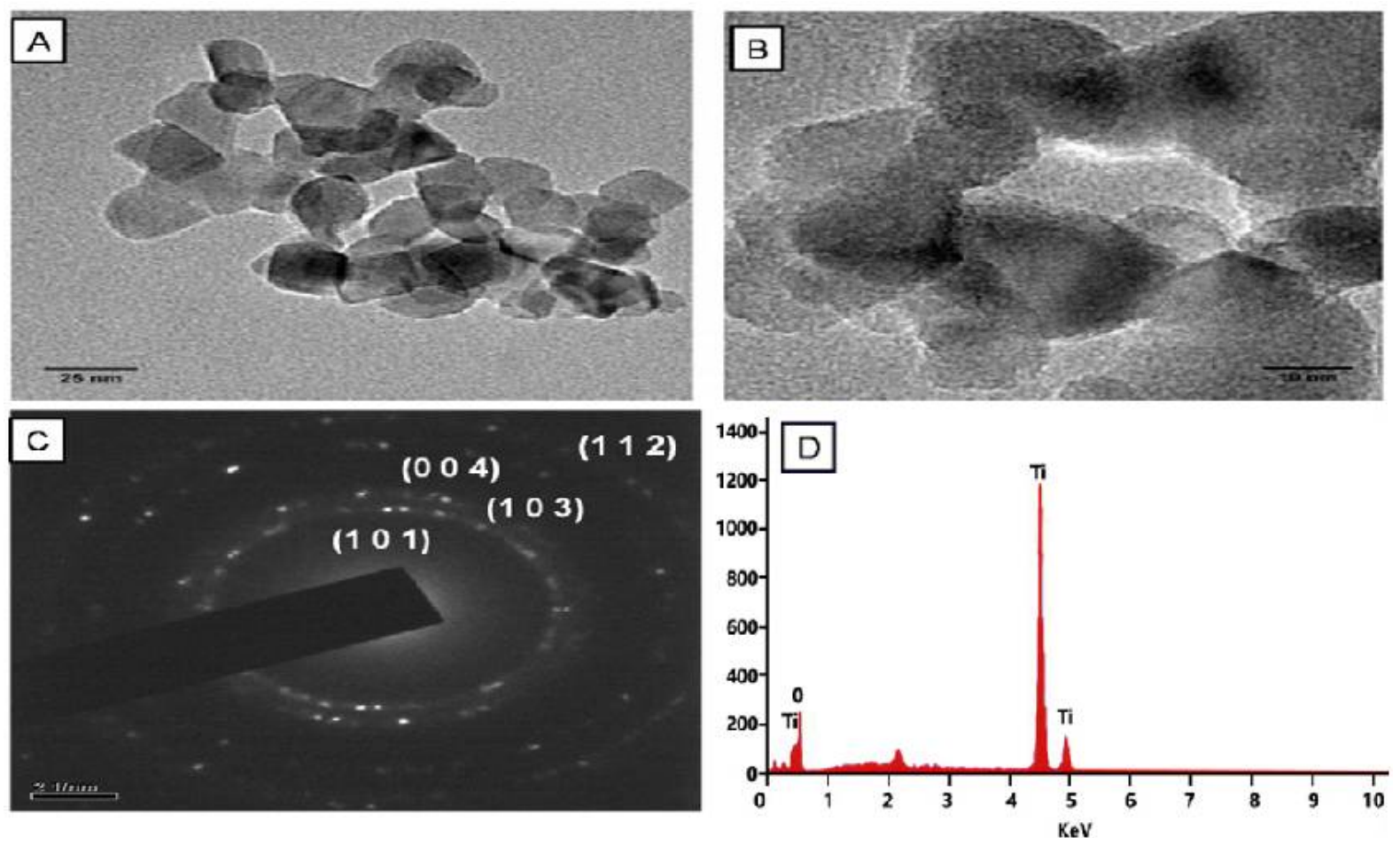

Figure 2: (A, B) Transmission electron microscopy (TEM) images of $\mathrm{TiO}_{2} \mathrm{NPs}$, (C) selected-area electron diffraction (SAED) pattern of the NPs, and (D) energy dispersive X-ray spectroscopy (EDS) profile showing the elements contained in the NPs 
The SAED pattern of the $\mathrm{TiO}_{2}$ NPs is shown in Figure $2 \mathrm{C}$. The dark rings correspond to the standard polycrystalline diffraction rings associated with the anatase phase (indexed). No other phases were observed in the diffraction rings. The EDS mapping of the NPs, shown in Figure $2 \mathrm{D}$, revealed the expected elements; no peaks other than the $\mathrm{TiO}_{2}$ peaks were observed

XPS analyses were carried out to determine the oxidation state of the $\mathrm{TiO}_{2} \mathrm{NPs}$. High-resolution XPS spectra (Figure 4) showed Ti $2 p$ and $O 1 s$ peaks. The binding energy at $459.2 \mathrm{eV}$ corresponds to $\mathrm{Ti} 2 \mathrm{p}_{3 / 2}$ spin-orbital splitting photoelectrons (Figure 4A), and the binding energy signal at $530.5 \mathrm{eV}$ is associated with $\mathrm{O} 1 \mathrm{~s}$ photoelectrons.

Fourier transform infrared spectroscopy (FT-IR) was performed to identify the possible reducing groups present in the leaf extract; the results are shown in Figure 5. In this spectrum, the peak at $3336.4 \mathrm{~cm}^{-1}$ represents the strong stretching vibration frequency of the hydroxyl $(-\mathrm{OH})$ group, and the peak at $1612.8 \mathrm{~cm}^{-1}$ corresponds to the stretching frequency of the $-\mathrm{C}=\mathrm{C}$ bonds. The bands at 1383.6 and $1520.4 \mathrm{~cm}^{-1}$ represent the $\mathrm{N}-\mathrm{H}$ bending mode. The band at $1022.2 \mathrm{~cm}^{-1}$ was assigned to the $\mathrm{C}-\mathrm{N}$ stretching vibration of the primary amines (Figure 6).

\section{In vitro cytotoxicity}

The in vitro cytotoxicity of the synthesized $\mathrm{TiO}_{2}$ NPs was also studied in an aqueous medium using D145 cells exposed to various concentrations of $\mathrm{TiO}_{2} \mathrm{NPs}(0.05,0.1$, and 0.5 $\mu \mathrm{g} / \mathrm{mL}$ ). The $\mathrm{TiO}_{2} \mathrm{NPs}$ were toxic to the D145 cells. The viability was $88 \%$ when the cells were treated with $\mathrm{a} \mathrm{TiO}_{2} \mathrm{NP}$ concentration of 0.05 $\mu \mathrm{g} / \mathrm{mL}$, and $38 \%$ when a concentration of 0.5 $\mu \mathrm{g} / \mathrm{mL}$ was used, as shown in Figure 7.

The cytotoxicity of $\mathrm{TiO}_{2} \mathrm{NPs}$ increased with NP concentration. From these results, we concluded that the cytotoxicity of the bio-fabricated $\mathrm{TiO}_{2}$ NPs was concentration dependent.
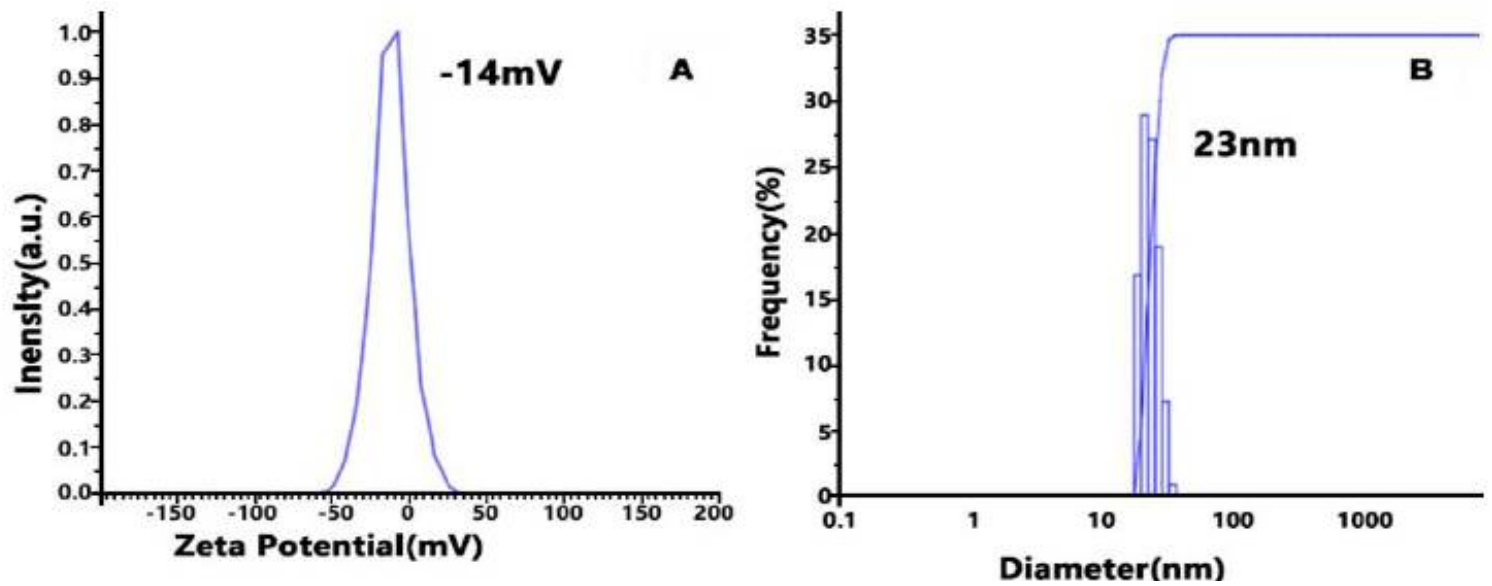

Figure 3: (A) Zeta potential value of $\mathrm{TiO}_{2} \mathrm{NPs}$ and (B) average size of the prepared NPs.
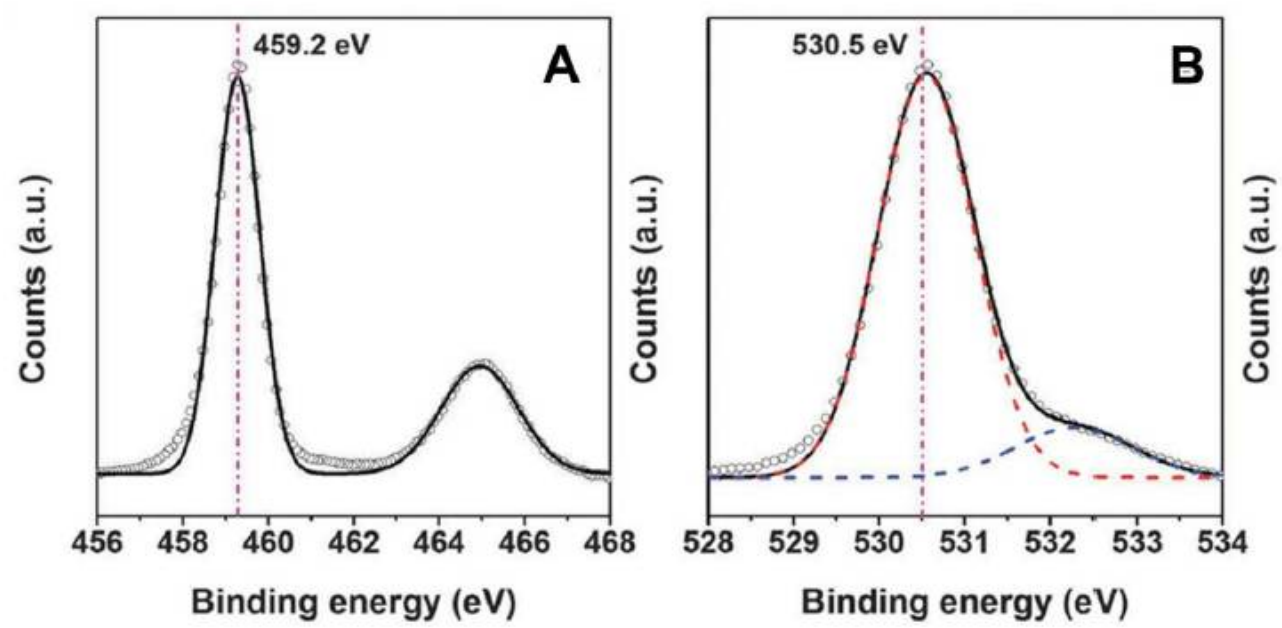

Figure 4: High-resolution x-ray photoelectron spectroscopy (XPS) spectra of (A) the titanium $2 p$ peak and (B) the oxygen 1s peak of $\mathrm{TiO}_{2} \mathrm{NPs}$ 


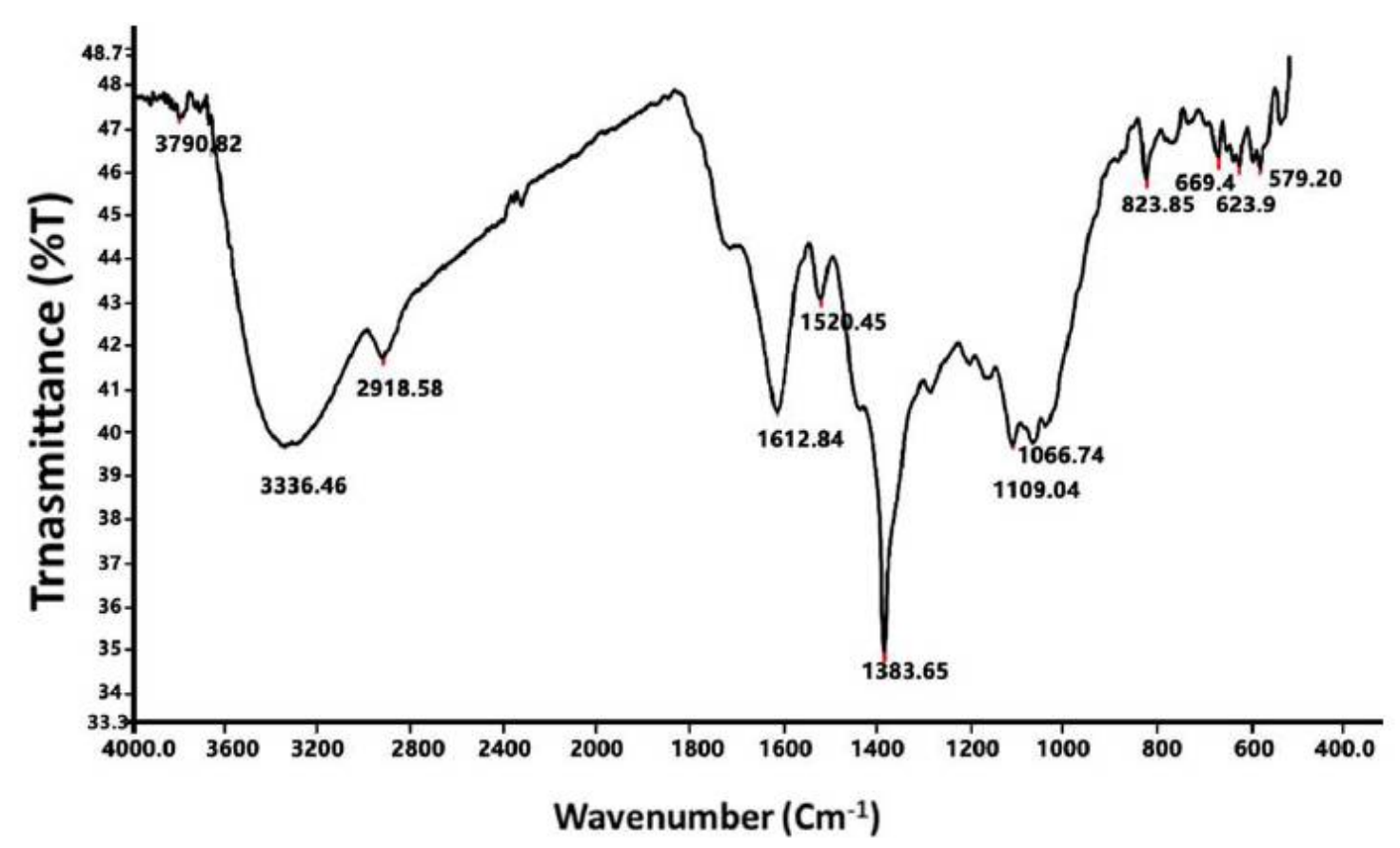

Figure 5: Fourier transform infrared (FT-IR) spectrum of $\mathrm{TiO}_{2} \mathrm{NPs}$ prepared using Cinnamomum tamala leaf extract

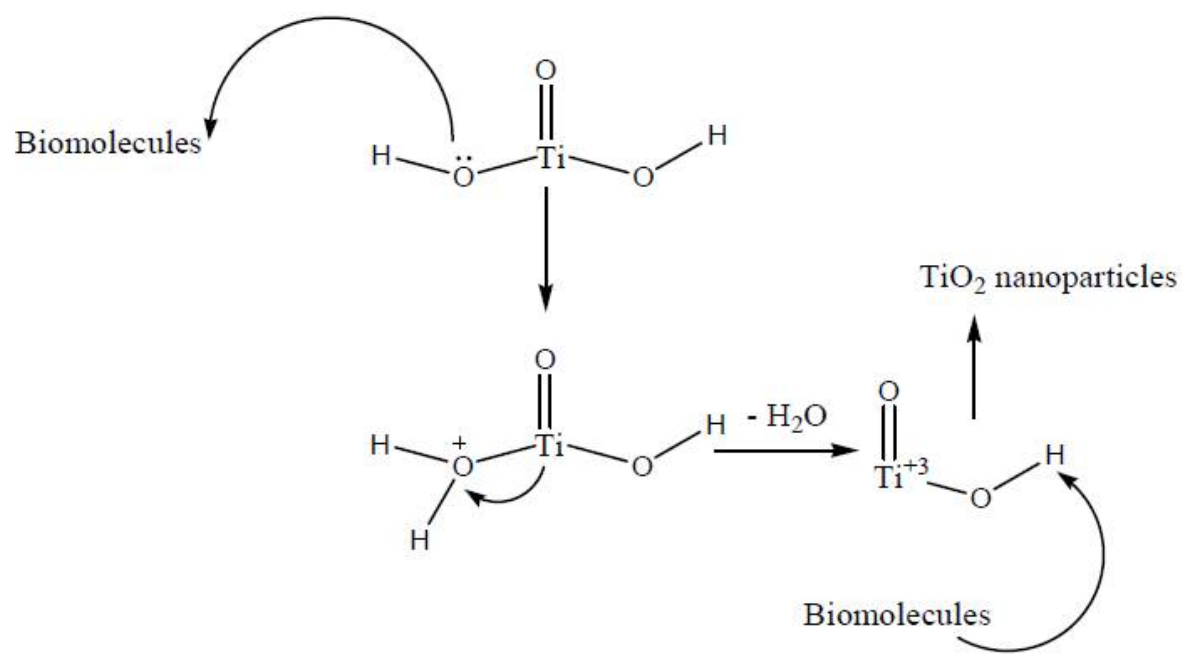

Figure 6: Plausible mechanism for the formation of $\mathrm{TiO}_{2} \mathrm{NPs}$

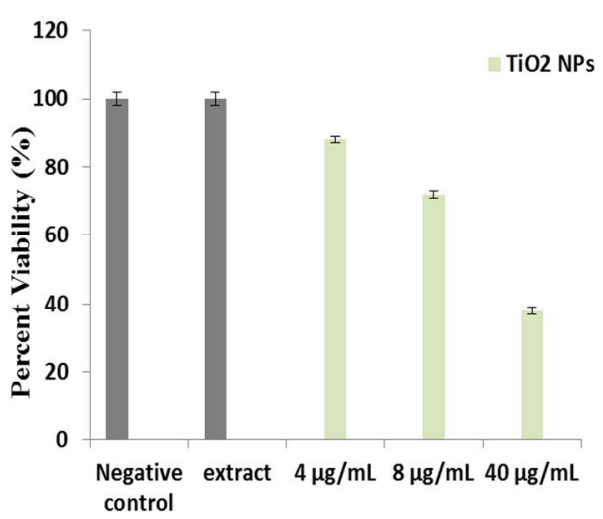

Figure 7: Viable D145 cells after exposure to $\mathrm{TiO}_{2}$ NPs

\section{DISCUSSION}

The biomolecules present in the leaf extract formed a thin organic layer on the NPs. This layer may act as a capping agent, as evidenced by the uniform distribution of NPs inside the bioreduced aqueous solution, even at the nanoscale level. Based on XPS data, $\mathrm{TiO}_{2} \mathrm{NPS}$ and titanium metal ions were present in their highest oxidation state $(+4)$. All of these results are in good agreement with previous reports [24,25], which confirmed the formation of pure, single-phase $\mathrm{TiO}_{2} \mathrm{NPs}$. 
FTIR spectra suggest that the secondary metabolites of the leaf extract contain a hydroxyl group that may possibly reduce the NPs. It is also believed that these groups are bound to $\mathrm{TiO}_{2}$ NPs via free carboxylate ions from amino acid residues containing hydroxyl functional groups.

The cytotoxicity of the bio-fabricated $\mathrm{TiO}_{2}$ NPs was concentration dependent. The concentration-dependence of the cytotoxicity of diastase-stabilized AgNPs towards mouse fibroblast (3T3) cell lines has already been reported [20]. Thus, $\mathrm{TiO}_{2} \mathrm{NP}$ synthesis using the method proposed could provide an important anticancer drug treatment.

\section{CONCLUSION}

$\mathrm{TiO}_{2}$ NPs have been successfully synthesized by an eco-friendly method using $C$. tamala leaf extracts. The NPs exhibited in vitro anticancer activity against D145 cells in a dose-dependent manner. Thus, the findings of this study provide evidence that useful anticancer compounds can be synthesized using plant-derived NPs.

\section{DECLARATIONS}

\section{Acknowledgement}

The authors gratefully acknowledge the help of The First Affiliated Hospital, Zhejiang University, Hangzhou City.

\section{Conflict of interest}

The authors declare no conflict of interest associated with this work.

\section{Author contributions}

We declare that this work was done by the author(s) named in the article and all liability pertaining to claims related to the content of the article will be borne by the authors. Feiping $\mathrm{He}$ and Weixing $\mathrm{Yu}$ played a key role in the preparation and characterization of $\mathrm{TiO}_{2} \mathrm{NPs}$. Xiaosong Fan and Baiye Jin conducted the cytotoxicity experiments for the prepared $\mathrm{TiO}_{2}$ NPs and helped in writing the manuscript.

\section{REFERENCES}

1. Seigneuric R, Markey L, Nuyten DSA, Dubernet $C$, Evelo $C T A$, Finot E, Garrido C. From nanotechnology to nanomedicine: applications to cancer research. Curr Mol Med 2010; 10: 640-652.
2. Liu Z, Kiessling F, Gatjens J: Advanced nanomaterials in multimodel imaging: design, functionalization and biomedical applications. J Nanomater 2010; doi:10.1155/2010/8943032010.

3. Nasrollahzadeh M, Sajadi SMJ. Green synthesis, characterization and catalytic activity of the Pd/TiO2 nanoparticles for the ligand-free Suzuki-Miyaura coupling reaction. Colloid Interf Sci 2016; 465: 121-127.

4. Nasrollahzadeh M, Sajadi SMJ. Synthesis and characterization of titanium dioxide nanoparticles using Euphorbia heteradena Jaub root extract and evaluation of their stability. Ceram Int 2015; 41: 14435-14439.

5. Akbar RV, Nasrollahzadeh $M, M$ Alizadeh. Green synthesis of perlite supported silver nanoparticles using Hamamelis virginiana leaf extract and investigation of its catalytic activity for the reduction of 4-nitrophenol and Congo red. J Alloy Compd 2016; 680: 309-314.

6. Nasrollahzadeh $M$, Sajadi SM, Hatamifard. Waste chicken eggshell as a natural valuable resource and environmentally benign support for biosynthesis of catalytically active Cu/eggshell, Fe3O4/eggshell and Cu/Fe304/eggshell nanocomposites. A Appl Catal B Environ 2016; 191: 209-227.

7. Nasrollahzadeh $M$, Sajadi SM, Rostami-Vartooni $A$, Bagherzadeh M, Safari R. Immobilization of copper nanoparticles on perlite: Green synthesis, characterization and catalytic activity on aqueous reduction of 4-nitrophenol. J Mol Cat A Chem 2015; 400: 22-30.

8. Gelis C, Girard S, Mavon A, Delverdier M, Pailous N, Vicendo $P$. Assessment of the skin photo protective capacities of an organomineral broad spectrum sunblock on two ex vivo skin models. Photodermatol Photoimmunol Photomed 2003; 19: 242-253.

9. Trouiller $B$, Reliene $R$, Westbrook $A$, Solaimani $P$, Schiestl $R H$. Titanium dioxide nanoparticles induce DNA damage and genetic instability in vivo in mice. Cancer Res 2009; 69: 8784-8789.

10. Fujishima $A$, Rao TN, Truk DA. Titanium dioxide photocatalysis. J Photochem Photobiol C Photochem 2000; 1: 1-21.

11. Haghi M, Hekmatafshar M, Janipour MB, Gholizadeh SS, Faraz MK, Sayyadifar F, Ghaedi M. Antibacterial effect of TiO2 nanoparticles on pathogenic strain of E. coli. Int J Adv Biotechnol Res 2012; 3: 621-662.

12. Hoffmann MR, Martin ST, Choi WY, Bahnemann DW. Environmental applications of semiconductor photocatalysis. Chem Rev 1995; 95: 69-96.

13. Frederickson CJ, Hernan-dez MD, Goik SA, Morton JD, McGinty JS. Loss of zinc staining from hippocampal mossy fibers during kainic acid induced seizures: a histofluorescence study. Brain Res 1988; 446: 383-392.

14. Behnajady MA, Eskandarloo H, Modirshahla N, Shokri M. Sol-gel low-temperature synthesis of stable anatasetype TiO2 nanoparticles under different conditions and its Photocatalytic Activity. Photochem. Photobiol 2011; 87: 1002-1008. 
15. Lee KH, Song SW. One-step hydrothermal synthesis of mesoporous anatase TiO2 microsphere and interfacial control for enhanced lithium storage performance. ACS Appl Mater Interfaces 2011; 3: 3697-3703.

16. Akuraj KK, Vital A, Fortunato G, Hany R, Nueesch $F$, Graule T. Flame synthesis of TiO2 nanoparticles with high photocatalytic activity. Solid State Sci 2007; 9: 247-257.

17. Khade GV, Suwarnkar MB, Gavade NL, Garadkar KM. Green synthesis of TiO2 and its photocatalytic activity. J Mater Sci Mater Electron 2015; 26: 3309.

18. Maddinedi SB, Mandal BK, Vankayala $R$, Kalluru $P$, Tammina SK, Kiran Kumar HA. Casein mediated green synthesis and decoration of reduced graphene oxide. Spectrochim. Acta Mol. Biomol. Spectrosc. 2014; 126: 227-231.

19. Maddinedi SB, Mandal BK, Vankayala R, Kalluru $P$, Pamanj SR. Bioinspired reduced graphene oxide nanosheets using Terminalia chebula seeds extract. Spectrochim. Acta Mol. Biomol. Spectrosc. 2015; 145: 117-124.

20. Maddinedi SB, Mandal BK, Anna KK. Environment friendly approach for size controllable synthesis of biocompatible Silver nanoparticles using diastase. Environ. Toxicol. Pharmacol. 2017; 49: 131-136. 